\title{
MICRO, SMALL, AND MEDIUM ENTERPRISES TAXPAYER PERCEPTION ON THE DETERMINATION OF FINAL INCOME TAX POLICY ACCORDING TO GOVERNMENT REGULATION NUMBER 23 YEAR OF 2018
}

\author{
Lina Said \\ Faculty Account, \\ Sekolah Tinggi Ilmu Ekonomi (STIE) Ekuitas, Indonesia \\ (Email: linasaid312@yahoo.com)
}

Accepted date: 14-04-2019

Published date: 11-07-2019

To cite this document: Said, L. (2019). Micro, Small, And Medium Enterprises Taxpayer Perception On The Determination Of Final Income Tax Policy According To Government Regulation Number 23 Year OF 2018. International Journal of Law, Government, and Communication, 4(15), 174-182.

DOI: $10.35631 /$ ijlgc. 4150018

\begin{abstract}
The Government has issued a new provision on Income Tax on Micro, Small, and Medium Enterprises (MSMEs), namely Government Regulation Number 23 Year of 2018 about Income Tax Of Businesses Received or Obtained by Taxpayers Who Have Certain Gross Circulation, effective from $1^{\text {st }}$ July 2018. The Government Regulation revokes Government Regulation Number 46 year of 2013 which has been effective for five years since its enactment on $1^{\text {st }}$ July 2013. This new regulation is considered very important, especially for MSMEs because it regulates the reduction in final income tax rates for MSMEs with a turnover of maximum Rp. 4.8 billion per year, to 0,5\% originally $1 \%$ (Government Regulation No.46/2013). The method used is descriptive analysis with a quantitative approach using questionnaires with respondents are MSMEs taxpayers in the knitting industry. The results of the research show that in general, knitting industry MSMEs do not know and understand about the implementation of Government Regulation Number 23 Year of 2018. Taxpayer's perception of fairness is at 3.04, Certainty at 3.14, Convenience 3.20, and Economy/Efficiency 3.50.
\end{abstract}

Keywords: Perception, Income Tax, MSMEs, Principle of Tax Collection

\section{Introduction}

Indonesia adheres to a self-assessment system tax system or taxpayers are given the trust to calculate/calculate, pay, and report their own taxes. Executive Director of the Center for Indonesia Taxation Analysis (CITA) Yustinus Prastowo assessed the level of compliance of the Indonesian people for taxes are still low. The low level of compliance is reflected in the tax coverage ratio (new realization ratio to potential) of 72\%. (Hendra Kusuma. 2018. www.detik.com). The ratio of tax revenue to GDP (tax ratio) in the 2014-2019 range ranges 
from 11\%-13.7\%, even decreasing from 2014 (2019 State Budget). This figure is still below the Philippines at 14\%, Malaysia 16\%, Thailand 17\%, South Korea 25\%, South Africa 27\%, and Brazil $34 \%$ far below the OECD country average of $34 \%$ or the minimum MDG requirement of $25 \%$.

The number of taxpayers is also not optimal, only 36,031,972 taxpayers in 2017, with details of 2,922,712 corporate taxpayers, 6,222,442 personal taxpayers, non-employees, and $26,886,818$ employees' taxpayers. Details of tax payments per type of tax in 2017, which is IDR 480 trillion in the form of VAT, IDR 208 trillion in the form of Corporate Income Tax, IDR 117 trillion in the form of Article 21 income tax, IDR 106 trillion in Final Income Tax, IDR 50 trillion in Oil and Gas Tax, IDR 16.7 trillion in P3, IDR 7,8 trillion in the form of Non-employee.

With the target of tax revenue in the 2019 State Budget reaching Rp1,786.4 trillion, the Directorate General of Taxes (DGT) is optimizing the tax revenue set above one thousand trillion. This figure is up by around $15.4 \%$ compared to the tax target in the 2018 State Budget of Rp1,548.5 trillion. In the 2019 State Budget, the Minister of Finance establishes various policies in the field of taxation, including Automatic Exchange of Information (AEoI), Tax Information and Data Systems, HR and Organizations, Taxpayer Compliance, Tax Incentives, Ease of Imports for Export Purposes (specifically facility development/expansion for small and medium industries), improving Dwelling Time, Customs and Excise Information Technology, and new Excise Goods (BKC).

The role of Micro, Small and Medium Enterprises (MSMEs) in the national economy is calculated to be quite large. This number reaches 99.9 percent and employment reaches 97 percent. (www.merdeka.com). MSMEs contribute to GDP up to 60.34 percent. The number of small businesses in Indonesia reached 93.4 percent, then medium businesses 5.1 percent, and the big ones were only 1 percent. Based on world bank research results, there are four problems, namely lack of access to finance, lack of access and business opportunities, human resource capacity and institutional MSMEs, as well as regulation and bureaucracy.

President Joko Widodo, through Government Regulation Number 23 of 2018 concerning Income Tax on Income from Businesses Received or Obtained by Taxpayers who Have Certain Gross Circulation officially revised the final Income Tax for Micro, Small and Medium Enterprises effective starting July 1, 2018 (www.liputan6.com). Now, the final Income Tax rate charged to MSME players is only pegged at 0.5 percent compared to the previous one which is worth 1 percent.

The issuance of Government Regulation 23/2018 as stated in the consideration of consideration and general explanation is to encourage the public to participate in formal economic activities, by providing convenience and more justice to taxpayers who have certain gross circulation for a certain period of time. Previously, in 2013, the government issued Government Regulation No. 46 of 2013 concerning MSMEs Income Tax, but in one of Fadli's (2015) studies, within the scope of Small Tax Office of Manado, there was a decline in taxpayer growth by $0.23 \%$, this indicates that the Directorate General of Tax's efforts to increase the potential for tax revenue, in particular, Tax on MSMEs is not achieved properly. Receipt of Income Tax Article 4 Paragraph (2) from MSMEs Income Tax for a period of seventeen months after the application of Government Regulation No. 46 of 2013 has fluctuated and is still in the very poor category. 
Of the three things that are the objectives of the law, namely justice, certainty and benefit of the most substantive law is justice (Gustav Radbruch). In terms of tariff rates, the decline from 1 percent to 0.5 percent is certainly welcomed by a number of MSME Taxpayers, although for a number of other MSME entrepreneurs it is still not considered fair. However, Government Regulation 23/2018 is quite fair by giving an option for MSME Taxpayers if they want their income to not be subject to Final Income Tax 0.5 percent of gross circulation but with the general rate of income tax imposed from net income. Provisions that contain elements of uncertainty can lead to injustice. Therefore, legal norms including tax provisions must be clear, certain and not cause multiple interpretations.

Universally, fair taxation must be based on the principle of ability to pay. So payment of taxes is based on the ability of taxpayers to carry the tax burden (Steven Utz in Ruston Tambunan, 2018). Government Regulation 23/2018 reflects justice more than Government Regulation No. 46 of 2013 previously because the imposition of income tax on MSMEs will ultimately be based on net income and subject to general tariffs based on the Income Tax Law.

The imposition of final Income Tax is only temporary. This study aims to analyze and describe the perception of taxpayers regarding the final income tax policy for MSMEs in terms of tax collection principles by Adam Smith, which includes Equality, Certainty, Convenience, and Economy/Efficiency.

\section{Literature Review}

\section{Tax}

Based on Law Number 28 of 2007 concerning General Provisions and Procedures for Taxation, Article 1 paragraph (1) states that Tax is a compulsory contribution to the state owned by an individual or entity that is compulsory under the Law, with no compensation directly and used for state purposes for the greatest prosperity of the people.

Meanwhile, according to P.J.A. Adriani in R. Santoso Brotodiharjo (1991:2), Taxes are contributions to the state (which can be imposed) which are owned by those who are obliged to pay according to the regulations, with no achievement back, which is directly appointed, and what is used is to finance expenses. General expenditure is related to the duty of the State which administers the government.

\section{Principles of Tax Collection}

In order to achieve the objective of tax collection, it is necessary to uphold the collection principles in choosing the alternative collection, so that there is confidentiality of tax collection with goals and principles that are still needed, namely understanding of certain tax treatment. The principles of tax collection are proposed in Adam Smith (1776), states that tax collection should be based on:

- Equality

Tax collection must be fair and equitable, i.e. taxes imposed on individuals who must be comparable to the ability to pay taxes or the ability to pay and in accordance with the benefits received. Fair means that each Taxpayer donates money for government expenditure in proportion to the interests and benefits requested.

- Certainty

The tax determination is not arbitrarily determined. Therefore, taxpayers must know clearly and surely the amount of tax payable, when to pay, and the deadline for payment. 
- Convenience

When the taxpayer must pay taxes should be in accordance with the times that do not make it difficult for taxpayers as an example when taxpayers earn income. This collection system is called Pay as you earn.

- Economy

Economically, the cost of collection and the cost of fulfilling tax obligations for taxpayers is expected to be as minimal as possible, as well as the burden is borne by taxpayers.

The principle of justice in the principles of tax legislation and in terms of its implementation must be held firm, even though justice is very relative. According to Richard A. Musgrave and Peggy B. Musgrave in Waluyo (2008:14), two types of tax collection principles of justice, namely:

1. Benefit Principle

In a fair taxation system, each taxpayer must pay taxes in line with the benefits he enjoys from the government. This approach is called Revenue and Expenditure Approach.

2. Ability Principle

In this approach, it is recommended that taxes be borne by taxpayers on the basis of ability to pay.

Another principle of the collection is also stated by John F. Due, which means that the tax must be neutral, meaning that it does not affect people's choice to consume or produce goods. It is seen that this principle aims to maintain that tax collection does not disrupt economic progress.

\section{Micro, Small and Medium Enterprises (MSMEs)}

MSMEs have definitions that vary depending on the perspective of each institution. The definition of MSMEs is very important given the limitations to classify whether a business is included in the MSME or not. Bank Indonesia (Admin: www.bi.go.id, 2011) states that the objectives related to the definition of MSMEs are two, namely administrative and regulatory goals. The first objective relates to provisions that require a company to fulfil its obligations, such as paying taxes, carrying out social and environmental responsibilities, and complying with labor regulations such as security and other workers' rights. While the second goal is more on the development of targeted policies such as coaching efforts, improving technical capabilities, and financing policies for MSMEs. Income Tax for MSMEs

In general, the tax obligations for MSMEs are (www.pajak.go.id):

a. Register yourself to get a tax ID and, or Taxable Firm

b. Deposit and report Income Tax and other taxes,

c. Collection of Value Added Tax, deposit and report it if it has been confirmed as Taxable Firm.

\section{Government Regulation No. 23 of 2018}

Article 3 of Government Regulation Number 23 of 2018 states that taxpayers who have certain gross circulation subject to final income tax are:

a. Individual taxpayers; and

b. Corporate taxpayers in the form of cooperatives, command partnerships, firms, or limited liability companies,

who receives or earns income with gross circulation does not exceed Rp.4,800,000,000.00 (four billion eight hundred million rupiahs) in 1 (one) Tax Year. 
Meanwhile, those that do not include taxpayers in terms of:

a. Taxpayers choose to be subject to Income Tax based on the rate of Article 17 paragraph (1) letter a, Article 17 paragraph (2a), or Article 31E of the Income Tax Law;

b. Taxpayers in the form of private partnership entities or firms formed by several taxpayers who have special expertise in delivering similar services with services related to free work as referred to in Article 2 paragraph (4);

c. Corporate taxpayers obtain Income Tax facilities based on:

1. Article 31A Income Tax Law; or

2. Government Regulation Number 94 of 2010 concerning Calculation of Taxable Income and Repayment of Income Tax in the Current Year along with changes or substitutes thereof; and

d. Taxpayers in the form of a permanent establishment of corporation.

The taxpayer must submit a notification to the Director General of Taxes. Taxpayers as referred to in paragraph (3), for the next Tax Year cannot be subject to Income Tax under this Government Regulation.

A certain period of the imposition of final income tax which is the longest:

a. 7 (seven) Tax Years for Individual Taxpayers;

b. 4 (four) Tax Years for corporate taxpayers in the form of cooperatives, cooperative partnerships, or firms; and

c. 3 (three) Tax Years for corporate taxpayers in the form of limited liability companies.

This period is calculated from:

a. Registered Taxpayer Tax Year, for Taxpayers, registered since the enactment of this Government Regulation, or

b. The tax year applies to this Government Regulation, for taxpayers who have registered before the enactment of this Government Regulation.

\section{Research Model}

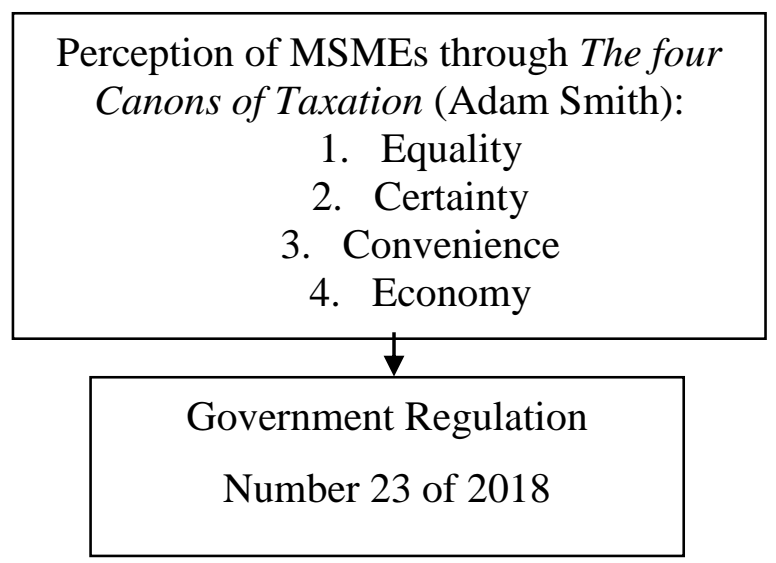

Figure 1. Research Model

\section{Research Method}

This research is a type of descriptive research, namely research conducted to find out and explain the characteristics of the variables studied in a situation (Sekaran, 2006:58).

The research used descriptive analysis method. The researcher described the perception of MSME taxpayers on the determination of final income tax policy in accordance with 
Government Regulation No. 23 of 2018 using a quantitative approach. The quantitative research described by Kasiram (2010:92) is a study conducted on measuring the measure in collecting data. The application of statistical methods in this study is descriptive statistics to collect, process, present, and analyze quantitative data descriptively.

\section{Types, Data Sources, Population and Samples}

Data collection is carried out by direct research to obtain primary data through field studies, by a census of the knitting industry MSMEs in Binong Bandung.

The population is the MSMEs Knit Industry taxpayer in the Binong Bandung area with a turnover of under Rp.4.8 billion with a total of 200 knitting industries, with respondents returning 40 questionnaires.

\section{Data Collection Technique}

The research method used a survey method or questionnaire. This technique gives the respondent the responsibility to read and answer questions. Data obtained from questionnaires are in the form of respondents 'identities and respondents' choice of choices which show the perception of MSME taxpayers. The data analysis phase carried out was Validity Test, Reliability Test, and Descriptive Data Analysis.

Micro, Small, And Medium Enterprises Taxpayer Perception On The Determination Of Final Income Tax Policy According To Government Regulation Number 23 Year Of 2018

\section{Equality Variable}

Table 1. Distribution of Equality Variable Value

Source: Processed Primary Data

\begin{tabular}{|c|r|c|c|c|c|}
\hline \multirow{2}{*}{ Question } & \multicolumn{5}{|c|}{ Answer } \\
\cline { 2 - 6 } & $\mathbf{1}$ & $\mathbf{2}$ & $\mathbf{3}$ & $\mathbf{4}$ & $\mathbf{5}$ \\
\hline $\mathbf{1}$ & $0 \%$ & $15 \%$ & $38 \%$ & $48 \%$ & $0 \%$ \\
\hline $\mathbf{2}$ & $0 \%$ & $13 \%$ & $65 \%$ & $23 \%$ & $0 \%$ \\
\hline $\mathbf{3}$ & $28 \%$ & $43 \%$ & $30 \%$ & $0 \%$ & $0 \%$ \\
\hline $\mathbf{4}$ & $0 \%$ & $30 \%$ & $48 \%$ & $23 \%$ & $0 \%$ \\
\hline $\mathbf{5}$ & $0 \%$ & $10 \%$ & $28 \%$ & $35 \%$ & $28 \%$ \\
\hline Average & $\mathbf{6 \%}$ & $\mathbf{2 2 \%}$ & $\mathbf{4 2 \%}$ & $\mathbf{2 6 \%}$ & $\mathbf{6 \%}$ \\
\hline
\end{tabular}

The results of the descriptive analysis of equality variables indicate that the Taxpayer's Perception of justice is at 3.04.

Determination of final income tax policy Government Regulation No. 23 of 2018 with a tax base through turnover still creates controversy in terms of justice as Government Regulation No. 46 of 2013. This regulation does not see whether MSME taxpayers suffer losses in their business because even the final loss cannot be compensated. Taxpayers feel more disagree with this. Individual taxpayers cannot use Non-Taxable Income as a deduction from income. Thus, there is no more consideration of the number of families that must be lived. Entrepreneurs with the same turnover must pay the same tax, even though their status and dependents are different. 


\section{Certainty Variable}

The results of the descriptive analysis of the certainty variable indicate that the Taxpayer's Perception of Certainty at 3.14 intervals.

Table 2. Distribution of Certainty Variable Value

Source: Processed Primary Data

\begin{tabular}{|c|c|c|c|c|c|}
\hline \multirow{2}{*}{ Question } & \multicolumn{5}{|c|}{ Answer } \\
\cline { 2 - 6 } & $\mathbf{1}$ & $\mathbf{2}$ & $\mathbf{3}$ & $\mathbf{4}$ & $\mathbf{5}$ \\
\hline $\mathbf{1}$ & $0 \%$ & $10 \%$ & $55 \%$ & $35 \%$ & $0 \%$ \\
\hline $\mathbf{2}$ & $0 \%$ & $10 \%$ & $55 \%$ & $35 \%$ & $0 \%$ \\
\hline $\mathbf{3}$ & $0 \%$ & $18 \%$ & $55 \%$ & $28 \%$ & $0 \%$ \\
\hline Average & $\mathbf{0 \%}$ & $\mathbf{1 3 \%}$ & $\mathbf{5 5 \%}$ & $\mathbf{3 3 \%}$ & $\mathbf{0 \%}$ \\
\hline
\end{tabular}

Determination of final income tax policy in accordance with Government Regulation No. 23 of 2018 is considered to be an unclear regulation. Many taxpayers do not understand this regulation. This is because there is still a lack of socialization delivered to taxpayers, especially individual taxpayers. The average Taxpayer feels that he has not received clear information regarding this Government Regulation. Although the government has carried out socialization through banners, internet media, most taxpayers still feel they have not understood this regulation correctly. They expect to get a more detailed explanation from the tax/fiscal apparatus regarding this regulation.

\section{Convenience Variable}

Based on descriptive analysis of convenience variables shows that Taxpayer's Perception of convenience is at 3.20

Table 3. Distribution of Convenience Variable Value

Source: Processed Primary Data

\begin{tabular}{|c|c|c|c|c|c|}
\hline \multirow{2}{*}{ Question } & \multicolumn{5}{|c|}{ Answer } \\
\cline { 2 - 6 } & $\mathbf{1}$ & $\mathbf{2}$ & $\mathbf{3}$ & $\mathbf{4}$ & $\mathbf{5}$ \\
\hline $\mathbf{1}$ & $10 \%$ & $0 \%$ & $50 \%$ & $40 \%$ & $0 \%$ \\
\hline $\mathbf{2}$ & $10 \%$ & $0 \%$ & $48 \%$ & $43 \%$ & $0 \%$ \\
\hline $\mathbf{3}$ & $10 \%$ & $0 \%$ & $48 \%$ & $43 \%$ & $0 \%$ \\
\hline $\mathbf{4}$ & $10 \%$ & $0 \%$ & $48 \%$ & $43 \%$ & $0 \%$ \\
\hline $\mathbf{5}$ & $10 \%$ & $20 \%$ & $48 \%$ & $23 \%$ & $0 \%$ \\
\hline Average & $\mathbf{1 0 \%}$ & $\mathbf{4 \%}$ & $\mathbf{4 8 \%}$ & $\mathbf{3 8 \%}$ & $\mathbf{0 \%}$ \\
\hline
\end{tabular}

Government Regulation No. 23 of 2018 aims to provide convenience in calculating, depositing, and reporting taxes for MSMEs. This regulation also aims to make taxpayers save time in fulfilling tax obligations. However, because there are many taxpayers who do not understand this regulation, more taxpayers answer in doubt. 


\section{Efficiency Variable}

Table 4. Distribution of Efficiency Variable Values

\begin{tabular}{|c|r|r|r|r|r|}
\hline \multirow{2}{*}{ Question } & \multicolumn{5}{|c|}{ Answer } \\
\cline { 2 - 6 } & $\mathbf{1}$ & $\mathbf{2}$ & $\mathbf{3}$ & $\mathbf{4}$ & $\mathbf{5}$ \\
\hline $\mathbf{1}$ & $0 \%$ & $0 \%$ & $70 \%$ & $30 \%$ & $0 \%$ \\
\hline $\mathbf{2}$ & $0 \%$ & $0 \%$ & $58 \%$ & $43 \%$ & $0 \%$ \\
\hline $\mathbf{3}$ & $0 \%$ & $10 \%$ & $43 \%$ & $48 \%$ & $0 \%$ \\
\hline $\mathbf{4}$ & $0 \%$ & $0 \%$ & $18 \%$ & $83 \%$ & $0 \%$ \\
\hline $\mathbf{5}$ & $0 \%$ & $0 \%$ & $38 \%$ & $63 \%$ & $0 \%$ \\
\hline $\mathbf{6}$ & $0 \%$ & $0 \%$ & $43 \%$ & $58 \%$ & $0 \%$ \\
\hline $\mathbf{7}$ & $0 \%$ & $0 \%$ & $58 \%$ & $43 \%$ & $43 \%$ \\
\hline Average & $\mathbf{0 \%}$ & $\mathbf{1 \%}$ & $\mathbf{4 6 \%}$ & $\mathbf{5 2 \%}$ & $\mathbf{6 \%}$ \\
\hline
\end{tabular}

Source: Processed Primary Data

The results of the descriptive analysis of the efficiency variable indicate that the Taxpayer's Perception of Economy/Efficiency is in the range of 3.50. Taxpayers owning MSMEs have limited administrative and preparation of financial reports. So with the enactment of Government Regulation No. 23 of 2018 taxpayer owners of MSMEs are given convenience to reduce the administrative burden in calculating the tax payable.

Compared with using the norm, according to the perception of taxpayers, Government Regulation No. 23 of 2018 is considered lighter and will provide benefits for taxpayers because the tariff is smaller than Government Regulation No.46 of 2013. However, the use of this Government Regulation is also set a deadline, which is 7 years for individual taxpayers, and 4 years and 3 years for Corporate Taxpayers. So that after this deadline expires, Taxpayers can no longer use this final Income Tax, so Taxpayers are required to do bookkeeping to determine the income and income tax payable.

\section{Conclussion}

The results of the study indicate that the perception of MSMEs Taxpayers on the application of Government Regulation No. 23 of 2018 as follows:

1. The taxpayer's perception of the final income tax policy for MSMEs reviewed by the principle of equality is stated at intervals of 3.04.

2. The taxpayer's perception of the final income tax policy for MSMEs, viewed from the certainty principle, is stated at an interval of 3.14.

3. Taxpayer perceptions of the final income tax policy for MSMEs are reviewed from the convenience principle stated at intervals of 3.20.

4. The taxpayer's perception of the final income tax policy for MSMEs in terms of the principle of economy/efficiency is expressed at intervals of 3.50 .

\section{Recommendations:}

1. The Directorate General of Taxes should be able to improve the perception of MSME taxpayers through socialization, publication, training, etc. through the Primary Tax Service Office by explaining in general the taxation system and its latest policies, such as an explanation of the intent and purpose of making a rule new taxation that affects MSME taxpayers to technical calculations.

2. Knowledge of taxation by MSME taxpayers who are better and more righteous can 
increase profits for the entire process of fulfilling tax obligations without having to violate the provisions of the Taxation Law. MSME taxpayers are expected to be sensitive and active towards tax regulations.

\section{References}

Adam Smith. (1776). An Inquiry, Into The Nature and Causes of the Wealth of Nations. London: Mutheun \& Co. Ltd

Anisa Nurpratiwi Muhammad Saifi Otto Budihardjo. (2014). Analisis Persepsi Wajib Pajak Pemilik UMKM Terhadap Penetapan Kebijakan Pajak Penghasilan Final Sesuai Peraturan Pemerintah No. 46 Tahun 2013

Dwi Aditya Putra. (2018). UMKM Sumbang 60 Persen ke Pertumbuhan Ekonomi Nasional, diakses pada 8 Januari 2018. www.merdeka.com

Due, John F. (1977). Government Finance: Economic of The Public Sector. Richard D. Irwin, INC.

Fadli Hakim' Grace B. Nangoi (2015). Analisis Penerapan PP. No.46 Tahun 2013 Tentang Pajak Penghasilan UMKM Terhadap Tingkat Pertumbuhan Wajib Pajak Dan Penerimaan PPh Pasal 4 Ayat (2) Pada KPP Pratama Manado.

Ghozali, Imam. (2006). Aplikasi Analisis Multivariate dengan Program SPSS. Cetakan Keempat. Semarang: Badan Penerbit Universitas Diponegoro.

Hendra Kusuma. (2018). Tingkat Kepatuhan Pajak Masyarakat RI Masih Rendah, diakses pada 8 Januari 2018. www.detik.com

Kasiram, Moh. (2010). Metodologi Penelitian. Yogyakarta: UIN-MALIKI PRESS.

Peraturan Pemerintah Republik Indonesia Nomor 46 Tahun 2013 Tentang Pajak Penghasilan atas Penghasilan Dari Usaha Yang Diterima Atau Diperoleh Wajib Pajak Yang Memiliki Peredaran Bruto Tertentu

Peraturan Pemerintah Republik Indonesia Nomor 23 Tahun 2018 Tentang Pajak Penghasilan Atas Penghasilan Dari Usaha Yang Diterima Atau Diperoleh Wajib Pajak Yang Memiliki Peredaran BrutoTertentu

Peraturan Menteri Keuangan Nomor 99/PMK.03/Tahun 2018 Tentang Pajak Penghasilan Atas Penghasilan Dari Usaha Yang Diterima Atau Diperoleh Wajib Pajak Yang Memiliki Peredaran Bruto Tertentu

R. Santoso Brotodiharjo. (1991). Dasar-dasar Hukum Pajak dan Pajak Pendapatan. Jakarta: Erlangga

Ruston Tambunan. (2018). OPINI: Mengupas Aturan Terbaru Pajak UMKM, diakses pada 8 Januari 2018. www.liputan6.com.

Sekaran, Uma. (2006). Metodologi Penelitian untuk Bisnis. Jakarta: Salemba Empat

Undang-undang Republik Indonesia Nomor 36 Tahun 2008 Tentang Perubahan Keempat atas Undang-Undang Nomor 7 Tahun 1983 Tentang Pajak Penghasilan

Undang-undang Republik Indonesia Nomor 20 Tahun 2008 Tentang Usaha Mikro, Kecil dan Menengah

Waluyo. (2008). Perpajakan Indonesia, Edisi kedelapan, Buku Satu. Jakarta: Salemba Empat 